\title{
KURANGNYA KOMPETENSI MENGAJAR GURU DAN SUPERVISI PENDIDIKAN SEHINGGA BERDAMPAK BURUK BAGI PRESTASI BELAJAR SISWA
}

\author{
Nama : MUKLIS
}

\section{Email: vf.muklis@gmail.com}

\begin{abstract}
ABSTRAK
Dalam upaya meningkatkan mutu pendidikan , kopetensi guru merupakan salah satu bagian yng sangat penting demi terlaksananya pendidikan yang berkualitas. Kompetensi guru tersebut meliputi kompetensi pedagigik, kompetensi personal, kompetensi sosial dan kopetensi profesional. Dan apabila semua kompetensi tersebut ada pada guru maka akan mempengaruhi prestasi belajar siswa dan meningkatkan mutu pendidikan. Serta peran penting supervisi pendidikan yang akan dilakukan oleh pihak kepala sekolah dan pengawas sekolah. Semuanya saling terkait demi tercapainya tujuan pendidikan itu sendiri dan meningkatkan prestasi belajar bagi siswa itu sendiri.
\end{abstract}

Kata kunci : kompetensi mengajar guru, prestasi belajar siswa, supervisi pendidikan

\section{A. LATAR BELAKANG}

Dalam pembangunan nasional yang menjadi tugas dan peranan penting adalah peninhgkatan kualitas sumber daya manusia (SDM). Berkaitan dengan usaha untuk menyiapkan sumber daya manusia yang berkualitas, maka pemerintah berusaha keras untuk meningkatkan pendidikan yang mencangkup berbagai aspek dari segala bidang yang salah satu diantaranya adalah bidang pendidikan. 
Pendidikan dipandang sebagai proses membawa manusia kearah kedewasaan. Pendidikan merupakan alat untuk mencapai cita-cita dan tujuan hidup manusia dan salah satu faktor untuk meningkatkan taraf hidup baik pembangunan fisik maupun mental. Dunia pendidikan dalam usaha pembangunan output yang berkualitas memiliki etos kerja yang tinggi, produktivitas, profesionalisme serta mampu menguasai dan mendapatkan ilmu pengetahuan dan teknologi melalui berbagai jalur pendidikan

Salah satu faktor luar siswa yang mendukung dalam mencapai prestasi belajar ini adalah dari kemampuan yang mantap yang dimiliki guru disamping cara pengajarannya. Guru yang lebih mampu menciptakan lingkungan belajar yang efektif dan akan lebih mampu mengelola kelas sehingga hasil belajar siswa berda pada tahapan optimal. Sehingga dengan kopetensi mengajar yang dimilikinguru akan dapat membangkitkan minat siswa dalam mengikuti pelajaran yang akhirnya dapat menunjang pencapaian prestasi belajar.

Permasalahan saat ini yaitu kopetensi mengajar guru banyak yang kurang dan tidak dapat untuk menciptakan lingkungan belajar yang efektif dan kurang mampu mengelola kelas dengan baik sehingga berdampak buruk bagi prestasi belajar siswanya dan juga berdampak panjang bagi siswanya tersebut yang tidak dapat bersaing dengan yang lain. Dan seharusnya guru harus mampu melakukan semua itu agar dapat menunjang prestasi belajar siswa, disini guru dituntut agar lebih cerdas dalam mengelola kelas dengan baik dan bijaksana sehingga pencapaian pendidikan dapat terlaksana dengan baik.

Disamping itu peranan penting supervisi juga berpengaruh besar dalam dunia pendidikan, yang mana perkembangan supervisi pendidikan berkembang seiring dengan perkembangan ilmu pengetahuan, teknologi, serta sosial ekonomi dan budaya masyarakat. Supervisi bergerak dari berbentuk inspeksi dimana otoritas lebih didominasi oleh supervisor, berkembang dalam bentuk kalaborasi antara supervisor dan guru bersama berinisiatif dan bertanggung jawab dalam meningkatkan kualitas pembelajaran, serta menumbuhkan budaya belajar pada guru untuk selalu meningkatkan kompetensinya (Subandi,2013).

Dan semua itu di pengaruhi juga oleh supervisi pendidikan yang terjadi saat sekarang yang mana supervisi dilakukan agar kondidsi pekerjaan yang sedang dilakukan dapat diketahui bagian-bagian yang perlu dihadapi. Kegiatan supervisi dapat dilakukan oleh kepala sekolah 
maupun pengawas sekolah, akan tetapi kebanyakan itu semua tidak terlaksana dengan baik sehingga mutu pendidikan di anggap kurang baik.

\section{B. RUMUSAN MASALAH}

1. Apa dampak yang diakibatkan oleh kurangnya kopetensi mengajar guru bagi siswa?

2. Apa yang dapat dilakukan untukn meningkatkan prestasi belajar siswa?

\section{TUJUAN}

Artikel ini bertujuan untuk mengetahui betapa pentingnya peran guru, dan supervisi pendidikan untuk terlaksannya prestasi belajar bagi siswa dan agar terlaksananya tujuan dari pendidikan itu sendiri.

\section{PEMBAHASAN}

Kompetensi menurut Suhaenah Suparno ( 2002:22) kompetensi biasa diartikan sebagai kecakapan yang memadai untuk melakukan tuags atau sebagai memiliki keterampilan dan kecakapan yang di syaratkan. Dalam pengertian ini jelas bahwa setiap cara yang digunakan dalam pengajaran yang ditujukan untuk mencapai kopetensi adalah untuk mengembangkan manusia yang memiliki pengetahuan, keterampilan dan kemampuan.

Guru merupakan jabatan atau profesi seseorang yang memerlukan keahlian khusus sebagai guru. Pekerjaan ini tidak bisa dilakukan oleh orang yang tidak memiliki keahlian untuk melakukan kegiatan atau pekerjaan sebagai guru. Guru yang bekualitas tentunya akan menunjang proses belajar siswa menjadi lebih baik lagi, disamping guru yang harus memiliki kopetensi di bidang mengajar kepala sekolah dan juga pihak pengawas harus benar-benar mampu mengawasi proses pembelajaran yang berlangsung dan dapat mengetaui terlaksa atau tidaknya proses belajar mengajar deng efektif.

Jadi kebanyakan yang terjadi pada saat ini kompetensi mengajar guru kuarang baik dan peran kepala sekolah maupun pengawas sekolah tidak telaksanan dengan baik sehingga berdampak kepada prestaisi belajar siswanya, dan juga tujuan dari pendidikan tersebut tidak terlaksana dengan baik sebagaimana seharusnya yang di inginkan.

\section{E. KESIMPULAN}


Dapat disimpulkan dari uraian-uraian diatas bahwasanya untuk terujudnya tujuan pendidikan dan meningkatkan prestasi belajar siswa dapat dilakukan dengan meningkatkan kualitas kompetensi mengajar guru dan serta peran aktif supervisi pendidikan yang dilaksanakan oleh kepala sekolah dan pengawas sekolah itu sendiri.

\section{F. SARAN}

Dengan meningkatnya kualitas pendidikan berati sumber daya manusia (SDM) yang terlahir akan semakin baik mutunya dan akan mampu membawa bangsa ini bersaing secara sehat dalam segala bidang, maka dari itu pemerintah harus berbenah untuk mengatasi permasalahan ini semua.

\section{SUMBER}

Nana Sudjana. 1990. Belajar Dan Faktor-faktor yang mempengaruhi. Jakarta : Renika Cipta

Subandi, A. (2013). Supervisi Pendidikan Untuk Pengembangan Profesionlitas Guru Supervisi Pendidikan Untuk Pengembangan Profesionalitas Guru Berkelanjutan Supervisi Pendidikan Untuk Pengembangan Profesionalitas Guru. Pedagogi, Jurnal Ilmiah Ilmu Pendidikan, Xiii(2), 1-9. Retreved From.

Http://Ejurnal. Unp.Ac.Id/Index.Php/Pedagogi/Aticle/View/4275

Sardiman AM. 1990. Interaksi dan Motivasi Belajar Mengajar. Jakarta. : Rajawali Pres.

https://www.goole.com/amp/s/munafiahqowsiy.wordpress.com/2015/09/08/tujuan-prinsip-fungsi-dan-abyeksupervisi-pendidikan/amp/?espv=1 